\title{
Isolation of a Phenol-degrading Bacterial Strain and Biological Treatment of Wastewater Containing Phenols
}

\author{
Hyun Don Lee, Myoung Eun Lee, Hyung Gab Kim and Hyun-Hyo Suh*
}

Department of Evironmental Engineering, Gyeongnam National University of Science and Technology, Jinju 660-758, Korea

Received August 26, 2013 /Revised October 7, 2013 /Accepted October 14, 2013

\begin{abstract}
Aromatic hydrocarbons, such as phenol, have been detected frequently in wastewater, soil, and groundwater because of the extensive use of oil products. Bacterial strains (56 isolates) that degraded phenol were isolated from soil and industrial wastewater contaminated with hydrocarbons. GN13, which showed the best cell growth and phenol degradation, was selected for further analysis. The GN13 isolate was identified as Neisseria sp. based on the results of morphological, physiological, and biochemical taxonomic analyses and designated as Neisseria sp. GN13. The optimum temperature and $\mathrm{pH}$ for phenol removal of Neisseria sp. GN13 was $32^{\circ} \mathrm{C}$ and 7.0 , respectively. The highest cell growth occurred after cultivation for 30 hours in a jar fermentor using optimized medium containing 1,000 $\mathrm{mg} / \mathrm{l}$ of phenol as the sole carbon source. Phenol was not detected after 27 hours of cultivation. Based on the analysis of catechol dioxygenase, it seemed that catechol was degraded through the meta- and ortho-cleavage pathway. Analysis of the biodegradation of phenol by Neisseria sp. GN13 in artificial wastewater containing phenol showed that the removal rate of phenol was $97 \%$ during incubation of 30 hours. The removal rate of total organic carbon (TOC) by Neisseria sp. GN13 and activated sludge was $83 \%$ and $78 \%$, respectively. The COD removal rate by Neisseria sp. GN13 from petrochemical wastewater was about 1.3 times higher than that of a control containing only activated sludge.
\end{abstract}

Key words: Neisseria species, phenol degradation, aromatic compound, pilot test, petrochemical wastewater

\section{서 론}

산업발전, 인구증가와 인구의 도시집중화로 인한 각종 화학 물질, 에너지, 농업 및 산업생산물의 수요증가와 함께 그 결과 발생하는 환경오염원은 점차 증가하고 있다. 자연계에 방출된 일부 물질은 자연계의 자정능력을 초월하여 분해되지 못하고 환경에 잔류함으로써 문제시 되고 있다[9]. 특히 화학공업의 발달에 따라 각종 공정에서 이용되고 있는 방향족화합물은 벤젠고리를 가지는 구조적 특징으로 인하여 대부분이 생체에 독성을 나타낼 뿐만 아니라 자연계에서 분해가 어려워 환경오 염의 주요 원인 물질로 대두되고 있으나, 그 사용량이 계속 증가하고 있다[6, 14, 22]. 석유화학물질 유래의 방향족화합물 은 전세계적으로 연간 약 3,500 만 톤 이상 생산되는 거대시장 을 이루는 화합물로서 분해과정에서 생기는 benzene, tolulene, xylene 으로부터 대부분 만들어진다. 그 중 phenol은 미 국 Environmental Protection Agency (E.P.A.)가 주요 오염물

\section{*Corresponding author}

Tel : +82-55-751-3340, Fax : +82-55-751-3484

E-mail : hhsuh@gntech.ac.kr

This is an Open-Access article distributed under the terms of the Creative Commons Attribution Non-Commercial License (http://creativecommons.org/licenses/by-nc/3.0) which permits unrestricted non-commercial use, distribution, and reproduction in any medium, provided the original work is properly cited.
질로 지정하고 있는 화합물로서 석유정제, 석유화학공업, 제 약회사, 페놀수지, 석탄전환공장과 전자산업 공장 등의 방류 수로부터 다량 유출되어 $200 \mathrm{mg} / 1$ 이하의 저 농도에서도 미생 물의 생장을 저해하여 폐수처리를 어렵게 하는 주요 환경오염 물질이다 $[9,15]$.

폐수로부터 phenol계 염소화합물의 제거는 화학적 산화, 용매추출, 활성탄에 의한 흡착 등으로 이루어진다. 그러나 최 근에 생물학적 처리방법이 더욱 중요하게 인식되어 phenol계 염소화합물을 분해할 수 있는 균주로는 Rhodococcus, Mycobacterium, Flavobacterium, Rhodococcus chlorophendicus, Pseudomonas putida, Pseudomonas pikettii, Cryptococcus elinovi와 Phanerochaete chrysosporium 등이 알려져 있다[2, 7, 11].

Phenol계 화합물은 미생물에 의하여 중간대사산물인 catechol로 hydroxylation되고 효소에 의하여 aromatic ring이 분 열되어 succinate와 acetyl-CoA로 되는 orthopathway와 acetaldehyde와 pyruvic acid로 분해되는 meta-pathway에 의하 여 분해된다[1, 19, 24].

난분해성 유독화학물질인 phenol을 처리함에 있어 미생물 을 이용한 생명공학기술은 물리 화학적 방법보다 경제적이고 효율적이며, 2차 오염의 염려가 없고 보다 광역적으로 사용할 수 있는 장점이 있다. 실제로 자연계에 널리 존재하는 다양한 미생물이 갖는 물질분해 및 변환기능을 이용할 경우 대부분의 유해화합물을 무독화 할 수 있다. 
최근 석유계 유기화합물의 처리를 위해 경제적이고 효율적 인 처리방법으로서 미생물을 이용한 생물학적 처리법이 많이 연구되고 있으며, 실제로 석유화학폐수의 효과적인 처리를 위 하여 중요한 역할을 담당하는 유용한 미생물을 자연계로부터 분리하여 난분해성 석유계화합물의 분해를 촉진시키기 위하 여 미생물을 이용한 연구가 진행되고 있다[2, 11, 23].

본 연구에서는 석유화학폐수에 함유되어 있는 난분해성 물 질인 phenol의 효과적인 분해를 위하여 자연계로부터 phenol 분해능이 우수한 미생물을 분리 동정하였으며, 최종 선별된 균주의 분해특성 및 phenol 함유 폐수에 미치는 영향 및 특성 에 대하여 조사하였다.

\section{재료 및 방법}

\section{Phenol 분해 균주의 분리 및 선별}

Phenol 분해 균주의 분리는 전국 각지에서 채집한 산업폐 수 및 산업폐기물 오염지역의 토양을 균주원 시료로 하여 멸 균된 증류수로 연속 희석한 후 희석액을 Luria-Bertani (LB) 평판 고체배지에 도말하여 나타난 집락을 분리용 고체 최소배 지에 접종하고 phenol을 각각 증기상태로 공급하면서 $25^{\circ} \mathrm{C}$ 에 서 약 5 일간 배양한 후 집락을 관찰하여 자화능이 우수한 균주 를 분리하여 1 차 선별하였다. 1 차 선별된 균주를 phenol 1,000 $\mathrm{mg} / \mathrm{l}$ 함유된 분리용 액체배지에 접종하여 $30^{\circ} \mathrm{C}$ 에서 3 일간 배 양한 후 phenol 분해능이 우수한 균주를 선별하였다. 분리용 액체최소배지의 배지 11 에 포함된 각 성분의 조성과 함량은 $\mathrm{NH}_{4} \mathrm{Cl} 1.0 \mathrm{~g}, \mathrm{~K}_{2} \mathrm{HPO}_{4} 4.35 \mathrm{~g}, \mathrm{NaH}_{2} \mathrm{PO}_{4} 3.9 \mathrm{~g}, \mathrm{MgSO}_{4} \cdot 7 \mathrm{H}_{2} \mathrm{O}$ $0.48 \mathrm{~g} \mathrm{CaCl}_{2} 0.03 \mathrm{~g}, \mathrm{FeSO}_{4} 0.01 \mathrm{~g}, \mathrm{MnCl}_{2} 0.01 \mathrm{~g}, \mathrm{CoCl}_{2} 0.001$ $\mathrm{g}, \mathrm{Na}_{2} \mathrm{MnO}_{4} 0.001 \mathrm{~g}$ 등[12]이며 $\mathrm{pH}$ 는 6.8로 조절하였다.

\section{분리균주의 동정 및 보존}

분리균주의 형태적, 생리적 그리고 생화학적 특징을 조사한 후 Bergey's manual of determinative bacteriology [21]와 Biochemical tests for the identification of medical bacteria (2nd ed)[16]에 따라서 균주 동정을 실시하였다. 각 균주의 DNA 염기조성 $(\mathrm{G}+\mathrm{C}$ 함량)은 Tamaoka와 Komagata [25]의 방법에 따라 reversed-phase HPLC에 의해 분석하였다. 분리 균주는 최소배지에 계대배양하여 보존하였고, 또한 ampoule 에 동결 건조하여 보관하였다.

\section{배양조건}

분리균주의 배양 및 특성조사를 위하여 phenol 1,000 mg/l 이 포함된 최소배지 $\left(\mathrm{NH}_{4} \mathrm{Cl} 2.10 \mathrm{~g}, \mathrm{~K}_{2} \mathrm{HPO}_{4} 4.35 \mathrm{~g}, \mathrm{KH}_{2} \mathrm{PO}_{4}\right.$ $1.70 \mathrm{~g}, \mathrm{MgSO}_{4} \cdot 7 \mathrm{H}_{2} \mathrm{O} 0.20 \mathrm{~g}, \mathrm{MnSO}_{4} \cdot 4 \mathrm{H}_{2} \mathrm{O} 0.05 \mathrm{~g}$, $\left.\mathrm{CaCl}_{2} \cdot 2 \mathrm{H}_{2} \mathrm{O} 0.03 \mathrm{~g}, \mathrm{FeSO}_{4} \cdot 7 \mathrm{H}_{2} \mathrm{O} 0.01 \mathrm{~g}\right) 50 \mathrm{ml}$ 을 $250 \mathrm{ml}$ Erlenmeyer flask에 넣은 후 전배양액을 $2.0 \%(\mathrm{v} / \mathrm{v})$ 되게 접종 하고, $\mathrm{pH} 7.0,30^{\circ} \mathrm{C}$ 에서 $150 \mathrm{rpm}$ 으로 72 시간 배양하여 분리
균주의 배양온도와 초발 $\mathrm{pH}$ 에 따른 phenol 분해능, 그리고 phenol의 농도에 따른 생육 정도를 검토하였다. 전배양액은 phenol $500 \mathrm{mg} / \mathrm{l}$ 이 포함된 최소배지 $50 \mathrm{ml}$ 을 $250 \mathrm{ml}$ Erlenmeyer flask에 넣고 분리균주를 1 백금이 접종하여 $30^{\circ} \mathrm{C}$ 에서 24 시간 배양한 배양액을 이용하였다. 또한 현장 폐수의 모델로 제조한 인공폐수는 peptone $6.0 \mathrm{~g}$, yeast extract 4.0 g, urea $1.0 \mathrm{~g}, \mathrm{NaCl} 1.0 \mathrm{~g}, \mathrm{~K}_{2} \mathrm{HPO}_{4} 0.1 \mathrm{~g}, \mathrm{KCl} 0.14 \mathrm{~g}, \mathrm{CaCl}_{2}$ $0.14 \mathrm{~g}^{\mathrm{MgSO}} 40.1 \mathrm{~g}$ 을 수도수 1 1에 녹인 후 $\mathrm{pH}$ 6.8로 조정하여 사용하였다[10].

\section{균체량 측정}

균체량은 분리균주의 배양액을 원심분리하여 얻은 균체를 증류수로 2 회 세척한 후 $105^{\circ} \mathrm{C}$ 에서 8 시간 건조시킨 다음 세포 건조중량(dry cell weight)으로 측정하였다.

\section{Phenol 분해능 측정}

Phenol의 분해율은 modified colorimetric assay [17]법을 사용하여 phenol 농도의 변화를 측정하여 결정하였다. Phenol 의 농도는 시료 $1 \mathrm{ml}$ 에 $2 \mathrm{~N} \mathrm{NH}_{4} \mathrm{OH} 50 \mu 1$ 와 2\% 4-aminoantipyrine $25 \mu \mathrm{l}$ 를 첨가하여 교반한 후 $8 \% \mathrm{~K}_{3} \mathrm{Fe}(\mathrm{CN})_{6} 25 \mu 1$ 를 넣고 원심분리하여 균체를 제거 시킨 후 $500 \mathrm{~nm}$ 에서 흡광도를 측정하였으며, 표준곡선에서 계산된 방정식에 의하여 $500 \mathrm{~nm}$ 에서의 흡광도를 농도로 환산하여 측정하였다. Phenol의 함량 변화를 확인하기 위한 phenol 함유 폐수에서의 phenol 정량은 HP-VOC capillary column $(90.0 \mathrm{~m} \times 530 \mu \mathrm{m} \times 3.00 \mu \mathrm{m})$ 을 장착 한 gas chromatograph (HP6890N, Hewlett Packard)로 분석 하였다. 분석 시 injector와 detector의 온도는 각각 $230^{\circ} \mathrm{C}$ 와 $250^{\circ} \mathrm{C}$ 였다. 운반기체 $\left(\mathrm{N}_{2}\right)$ 의 유속은 $30 \mathrm{~m} / \mathrm{min}$ 로 유지하였으 며, 시료의 주입량은 $1.0 \mu 1$ 였다.

\section{효소활성 측정}

분리균주의 배양액 균체를 $0.05 \mathrm{M}$ phosphate buffer (pH 6.8)에 현탁 시킨 후 초음파로 균체를 파쇄한 다음 균체추출물 을 조효소로 이용하여 catechol 1.2-dioxygenase의 활성은 Hegeman [8]의 방법에 따라 catechol을 기질로 하여 $260 \mathrm{~nm}$ 에서 흡광도를 측정하였다. Catechol 2,3-dioxygenase의 활성 은 Nozaki [20]의 방법에 따라 $375 \mathrm{~nm}$ 에서 흡광도를 측정하였 다. 효소의 활성은 실온에서 반응액의 흡광도 증가치를 측정 하여 분당 cathechol $1 \mu \mathrm{M}$ 을 분해하는 양을 1 unit로 정하였다.

\section{호흡율 조사와 폐수의 성상분석}

호흡율 조사는 폭기조에서 채취한 시료를 폭기조 내 생물량 을 기준으로 이들의 호흡에 영향을 미치는 원인인자를 조사하 기 위하여 산소 소모율을 조사하였으며, 단위 시간당 소비되 는 산소 농도를 측정하여 폐수에 대한 미생물의 호흡률을 계 산하였다. 대상폐수의 $\mathrm{COD}_{\mathrm{Mn}}$ (chemical oxygen demand), 
MLSS (mixed liquor suspended solid)와 TOC (Total organic carbon) 농도 측정은 Standard Method [3]에 준하여 분석하였 으며, 용존 TOC (Total organic carbon) 농도는 시료를 12,000 $\mathrm{rpm}$ 으로 원심분리 한 후 상등액을 Whatman membrane filter $(0.45 \mu \mathrm{m})$ 를 이용하여 cell을 완전히 제거시킨 후 TOC 분석기 (TOC-V CPH, Shimazu)로 분석하였다. TOC는 TC (total carbon)에서 IC (inorganic carbon)를 제외한 값으로 산출하였다.

\section{처리효율 시험}

Phenol 함유 폐수 및 석유화학폐수의 처리효율 시험을 위 한 실험실 규모의 반응조는 활성오니 공정과 접촉산화식 공정 을 병행하여 운전할 수 있도록 설계하였다. 실험실 규모의 장 치는 용량 21 의 투명 아크릴판을 이용하여 제작하였으며, 공 기는 반응조의 바닥에 산기석을 설치하고 air blower에 연결 하여 폭기 하였다. 반응조 내에 $\mathrm{DO}$ 농도는 air blower를 조절 하여 $2 \sim 3 \mathrm{mg} / \mathrm{l}$, 온도는 자동조절기를 이용하여 $25 \pm 2{ }^{\circ} \mathrm{C}$, 그리 고 수리학적 체류시간 (HRT)은 24시간으로 유지하였으며 $\mathrm{pH}$ 는 7.0 으로 조절하였다.

\section{결과 및 고찰}

Phenol 분해 균주의 선별

Phenol 분해 균주의 분리는 전국 각지에서 채집한 산업폐 수 및 산업폐기물 오염지역의 토양을 균원 시료로 하여 phe$n o l$ 을 유일 탄소원으로 첨가한 최소 고체배지를 이용하여 56 균주를 순수분리 하였으며 이 중 phenol의 분해 활성이 우수 한 균주를 선별하였다. 1 차 선별은 phenol을 증기상으로 공급 하면서 $30^{\circ} \mathrm{C}$ 에서 5 일간 고체배양 하였을 때 세균 집락 형성능 이 뛰어난 균주를 선별하였다. 분리용 액체 최소배지에 첨가 한 phenol의 양은 phenol의 용해도, 미생물에 미치는 일반적 인 독성과 배지에서의 잔류 정도 등을 고려하여 $1,000 \mathrm{mg} / 1$ 으 로 결정하였다[22, 23].

이들 균주 중 phenol을 공급한 액체 최소배지에서 phenol 분해능과 균체생육이 가장 우수한 균주인 GN13을 최종 선별 하여 실험에 이용하였다. 최종 선별된 분리균주 GN13은 석유 계 산업폐기물 오염지역의 토양으로부터 분리되었으며, 분리 용 액체 최소배지에서의 phenol 분해율은 $67 \%$ 로 나타났다.

\section{분리균주의 동정}

분리 균주의 동정을 위하여 형태학적, 생리학적, 생화학적 특성을 조사하였다(Table 1). 분리균주 GN13은 glucose-nutrient agar 배지와 Luria-Bertani 배지에서 생육이 좋았으며, 누르스럼한 색의 집락을 형성하였다. 분리균주는 Gram 음성 구균으로서 크기는 $0.7 \mu \mathrm{m}$ 이었고 포자를 형성하지 않았고 운 동성이 없었다. Catalase와 oxidase를 생성하였고 Voges-proskauer (VP) test와 indole test에서는 음성반응을 보였으며 ni-
Table 1. Taxonomical properties of isolated strain

\begin{tabular}{|c|c|}
\hline Characteristics & Selected strain GN13 \\
\hline \multicolumn{2}{|l|}{ Morphological } \\
\hline Gram staining & - \\
\hline Shape & cocci \\
\hline Size & $0.7 \mu \mathrm{m}$ \\
\hline Spore & - \\
\hline Motility & - \\
\hline Acid fast & - \\
\hline \multicolumn{2}{|l|}{ Cultural } \\
\hline Colony color & yellowish \\
\hline Growth in air & + \\
\hline Growth anaerobically & - \\
\hline Growth at $25^{\circ} \mathrm{C}$ & + \\
\hline Growth at $40^{\circ} \mathrm{C}$ & + \\
\hline Growth at $65^{\circ} \mathrm{C}$ & - \\
\hline Growth at $\mathrm{pH} 5.7$ & + \\
\hline Growth at $7 \% \mathrm{NaCl}$ & - \\
\hline \multicolumn{2}{|l|}{ Physiological } \\
\hline Catalase & + \\
\hline Oxidase & + \\
\hline O/F (Oxidation/Fermentation) & $\mathrm{O}$ \\
\hline \multicolumn{2}{|l|}{ Carbohydrates, acid form } \\
\hline glucose & + \\
\hline lactose & - \\
\hline sucrose & - \\
\hline xylose & - \\
\hline \multicolumn{2}{|l|}{ Hydrolysis of } \\
\hline gelatin & - \\
\hline starch & - \\
\hline Voges-Proskuer reaction & - \\
\hline Nitrate reduction & + \\
\hline Indole reduction & - \\
\hline Urease & - \\
\hline \multicolumn{2}{|l|}{ Chemical } \\
\hline $\mathrm{Mol} \% \mathrm{G}+\mathrm{C}$ of DNA & 52 \\
\hline
\end{tabular}

trate test에서는 양성을 나타내었다. 균의 생육은 $25^{\circ} \mathrm{C}$ 와 $40^{\circ} \mathrm{C}$ 에서는 생육을 잘 하였으나, $65^{\circ} \mathrm{C}$ 에서는 전혀 생육하지 못하 였다. Glucose에서는 산을 생성하였으나 lactose, sucrose와 xylose와 같은 당류에서는 산을 생성하지 못하였다. 분리균주 의 $\mathrm{G}+\mathrm{C}$ mole 함량은 $52 \%$ 로 나타났다. 분리균주 $\mathrm{GN} 13$ 의 형 태학적, 생리학적 분석에서 나타난 결과 Neisseria 속 세균과 유사한 것으로 동정되었으며 최종적으로 Neisseria sp. GN13 으로 명명하였다.

\section{Phenol 분해조건}

분리균주 Neisseria sp. GN13을 이용하여 phenol 1,000 mg/ 1 를 유일 탄소원으로 첨가한 액체 최소배지에 배양하여 배양 온도와 초기 $\mathrm{pH}$ 의 영향에 따른 균체생육 및 phenol 분해능을 조사하였다. 분리균주의 균체 생육 및 phenol 분해능에 미치 는 온도의 영향을 조사하기 위하여 $10^{\circ} \mathrm{C}$ 부터 $40^{\circ} \mathrm{C}$ 까지 조사한 결과(Fig. 1), $32^{\circ} \mathrm{C}$ 에서 균체생육과 phenol 분해능이 가장 높게 나타났으며, $20^{\circ} \mathrm{C}$ 이하의 저온에서는 균체생육 및 phenol 분 


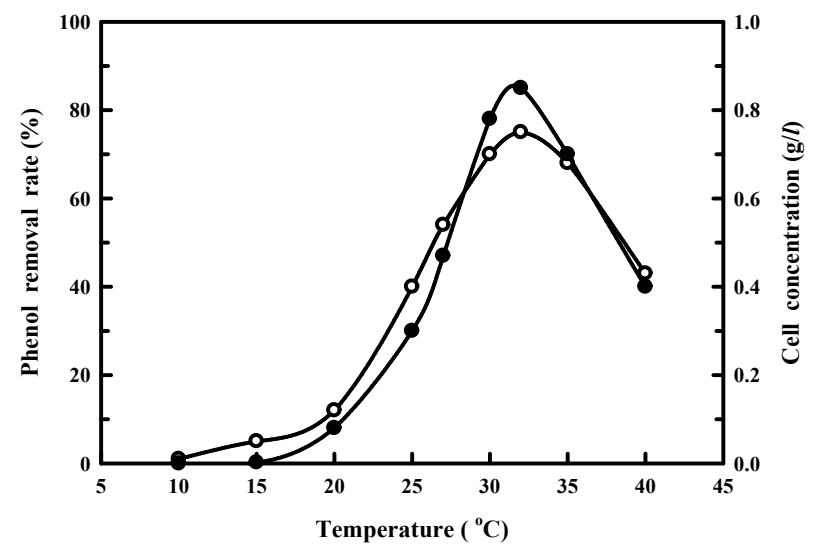

Fig. 1. Effect of temperature on the growth and phenol degradation by Neisseria sp. GN13. The symbols; $\bigcirc$ : cell concentration, $\bullet$ phenol removal rate.

해능이 거의 나타나지 않았다. 이와 같은 결과는 방향족화합 물의 경우 낮은 온도는 탄화수소의 물리적 성질을 결정하는 주된 요인으로 작용하기 때문에 $20^{\circ} \mathrm{C}$ 이하의 낮은 온도에서 미생물의 탄화수소 분해속도는 급격히 감소한다는 보고[22]와 일치하였으며, 또한 분리균주의 균체생육과 phenol 분해능은 상관관계가 매우 높은 것으로 나타났다.

분리균주에 의한 phenol 분해능과 균체생육에 미치는 $\mathrm{pH}$ 의 영향을 조사하기 위하여 최소배지의 초기 $\mathrm{pH}$ 를 3.0에서 10.0 으로 각각 조절하여 배양한 결과(Fig. 2) Neisseria sp. $\mathrm{GN13}$ 는 $\mathrm{pH}$ 7.0에서 가장 높은 phenol 분해능을 나타내었으 며 $\mathrm{pH}$ 6.5와 8.0의 범위에서 높은 균체생육과 phenol 분해능 을 나타내었다. 이상의 결과에서와 같이 Neisseria sp. GN13은 비교적 넓은 범위의 온도와 $\mathrm{pH}$ 에서 활발한 균체생육과 높은 phenol 분해능을 나타내어 phenol을 함유한 석유화학폐수, phenol 수지 폐수 등의 폐수처리 시 발생하는 다양한 온도와 $\mathrm{pH}$ 변화에도 효과적으로 처리할 수 있는 적합한 균주로 생각 된다.

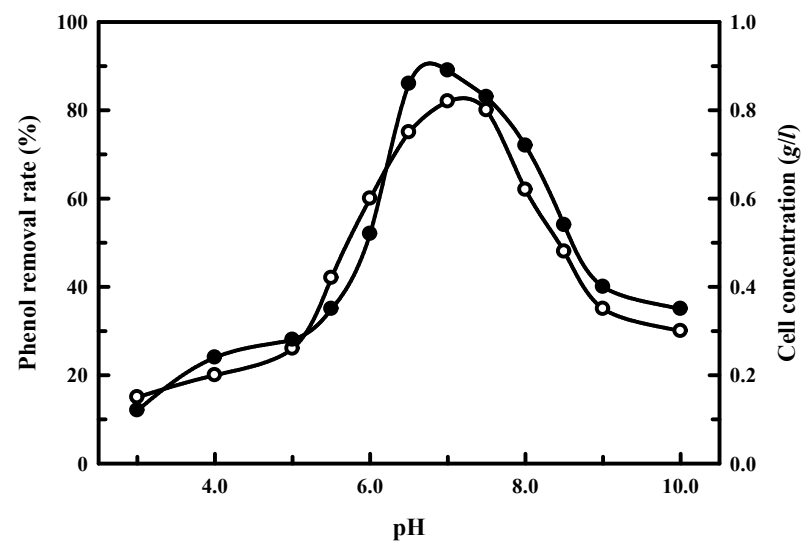

Fig. 2. Effect of $\mathrm{pH}$ on the growth and phenol degradation by Neisseria sp. GN13. The symbols; $\bigcirc$ : cell concentration,

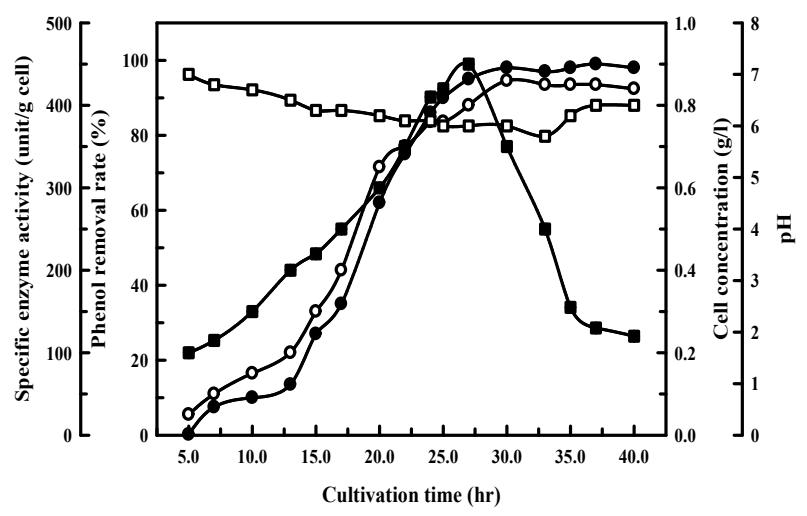

Fig. 3. Time course of phenol degradation by Neisseria sp. GN13 in the jar-fermentor. The symbols; $\bigcirc$ : cell concentration, ๑: phenol concentration, $\square: \mathrm{pH}, \mathbf{\square}$ : specific enzyme activity (catechol 2,3-dioxygenase).

\section{Jar-Fermentor 배양에서의 phenol 분해}

분리균주 Neisseria sp. GN13의 배양시간에 따른 phenol 분 해능을 조사하기 위하여 jar-fermentor 배양에서 배양 온도와 $\mathrm{pH}$ 를 최적화된 조건인 $32^{\circ} \mathrm{C}$ 와 $\mathrm{pH} 7.0$ 으로 조절하였으며, phenol $1,000 \mathrm{mg} / \mathrm{l}$ 이 포함된 배지에서 48 시간 배양하였다. 이때 통기량은 $1 \mathrm{vvm}$, 교반속도는 300 400 rpm으로 유지하였다.

분리균주 Neisseria sp. GN13 균주의 균체생육, phenol 분해 능과 효소활성을 배양시간 별로 측정한 결과(Fig. 3), 균체량 증가에 따라서 phenol의 분해가 잘 일어남을 확인할 수 있었 다. Jar - fermentor 배양 시 균체생육은 배양 30시간에서 최대 생육을 나타내었으며, 배양액 내에서의 phenol의 분해능을 조 사한 결과 배양 27 시간 이후 phenol은 배양액에서 거의 검출 되지 않았다.

분리균주 Neisseria sp. GN13의 cathechol oxygenase의 활 성을 조사한 결과, catechol 2,3-dioxygenase의 활성이 높게 나 타나 주로 metapathway를 통하여 catechol이 분해되는 것으 로 생각되며, catechol 1,2-dioxygenase의 활성도 나타내어 $a r-$ thopathway에 의해서도 일부 분해되는 것으로 생각된다. 주 분해효소인 catechol 2,3-dioxygenase의 specific enzyme activity은 배양 27시간째 가장 높은 활성(432.3 unit/g - cell)을 나타내었다. 단위 중량의 균체에 대한 catechol 2,3-dioxygenase의 specific enzyme activity은 균체의 증식과 함께 증가하 는 양상을 보였으며 균체 증식이 활발한 대수증식기에 가장 높게 나타났고, phenol이 소모 되었을 때는 효소활성이 급격 히 줄어드는 것을 확인할 수 있었다.

\section{Phenol 농도의 영향}

인공폐수상에서의 phenol 농도에 따른 Neisseria sp. GN13 의 phenol 분해능 및 균체생육을 조사하기 위하여 phenol의 농도를 $500 \mathrm{mg} / 1$ 에서 $3,500 \mathrm{mg} / 1$ 의 농도로 첨가하여 30시간 동안 배양하여 조사한 결과 Fig. 4 와 같다. 인공폐수 배양액 내 phenol 농도가 500 1,500 mg/1까지 첨가되었을 때 완전한 


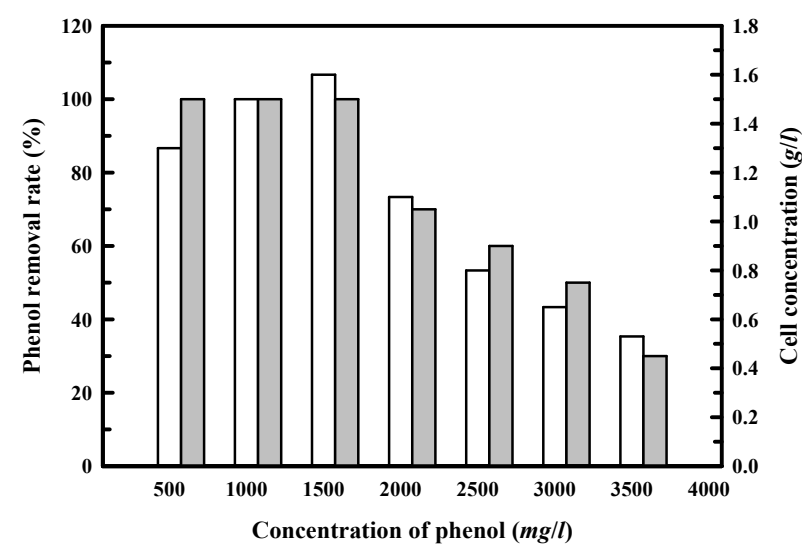

Fig. 4. Effect of phenol concentration on the degradation of phenol in continuous culture. The symbols; $\square$ : cell concentration, $\mathbf{\square}$ : phenol removal rate.

분해가 일어났으며, 균체의 생육은 phenol $1,500 \mathrm{mg} / \mathrm{l}$ 농도에 서 최대에 이르렀다. 일반적으로 벤젠고리를 가지는 방향족 화합물들은 균체에 독성을 나타내기 때문에 균체성장에 대하 여 기질저해효과를 나타낸다고 보고되어 있다[5], 그러나 분리 균주 Neisseria sp. GN13의 경우, $2,000 \mathrm{mg} / 1$ 이상의 고농도 phenol에서도 균체생육과 함께 약 30 60\% 의 phenol이 분해 되는 것을 확인할 수 있었다. 이러한 결과는 Lee 등[13]과 Masque 등[18]이 보고한 Pseudomonas 속의 세균이 phenol $1,000 \mathrm{mg} / 1$ 첨가된 배지에서 생육이 가능하다는 보고보다 나 은 결과를 나타내었다.

\section{Phenol 함유 폐수의 pilot test}

Phenol을 함유한 인공폐수를 처리하기 위하여 실험실 규모 의 아크릴 반응조(2 l)를 사용하였으며, 분리균주 Neisseria sp. $\mathrm{GN13}$ 의 폐수 내 phenol 분해능을 검토하기 위하여 연속실험 을 진행하였다. 처리효율 시험은 phenol 분해균주 Neisseria sp. GN13 처리구와 기존 현장의 활성슬러지를 대조구로 하여 처리효율 시험을 수행하였다. 두 개의 pilot을 대조구와 실험 구로 하여 60 시간 동안의 변화를 조사하여 phenol 함유폐수의 연속배양에 의한 분해결과를 Fig. 5 에 나타내었다. 활성슬러지 를 투입한 대조구의 phenol은 배양 50시간이 경과하였을 때 $86 \%$ 의 제거 효율을 나타내었고, 분리균주 Neisseria sp. GN13 을 첨가한 처리구에서는 배양 30시간 만에 $97 \%$ 의 phenol이 제거되어 활성슬러지를 처리하였을 경우 보다 분리균주 Neisseria sp. GN13을 투입한 경우 더 효율적인 처리가 일어나 는 것을 확인할 수 있었다.

또한 phenol 함유 폐수내의 phenol 함량 감소를 확인하기 위하여 배양 $0,10,20,30$ 과 40 시간의 배양액으로부터 phenol 을 추출하여 gas chromatograph로 검출한 결과 배양시간이 경과함에 따라 phenol 함량이 감소하는 것을 확인할 수 있었 다(data not shown). 시험기간 동안 $\mathrm{pH}$ 는 감소하기 시작하여 처리가 끝난 후 약산성 영역으로 유지되었다. 이는 phenol 분

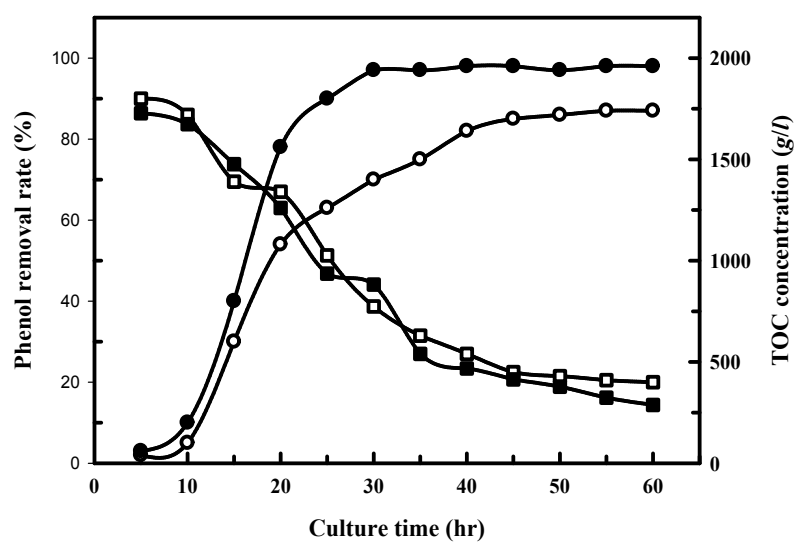

Fig. 5. Bench scale pilot test of artificial wastewater containing phenol. Treatment of phenol wastewater was done at $25 \pm 2{ }^{\circ} \mathrm{C}, \mathrm{pH} 7.0$ for $60 \mathrm{hr}$ on bench scale pilot. The symbols; $\bigcirc$ : activated sludge (phenol), o: Neisseria sp. GN13 (phenol), $\square$ : activated sludge (TOC), $\mathbf{\square}$ : Neisseria sp. GN13 (TOC)

해 시 미생물의 활발한 증식활동에 의하여 생산되는 대사산 물, 즉 유기산의 영향에 기인하는 것으로 생각 된다. TOC 제거 효율은 대조구와 분리균주 처리구에서 배양 60 시간째 각각 $78 \%$ 와 $83 \%$ 제거되었으며, 대조구와 처리구에서 큰 차이는 나 타나지 않았다.

\section{석유화학폐수의 처리}

분리균주 Neisseriasp. GN13의 실제 산업폐수에서의 처리 효율을 조사하기 위하여 석유화학공장에서 채취한 석유화학 폐수를 이용하였다. 석유화학폐수 원폐수의 $\mathrm{COD}_{\mathrm{Mn}}$ 값은 4,378 $\mathrm{mg} / \mathrm{l}$, 총유기탄소량(TOC)은 $5,274 \mathrm{mg} / 1$ 로 높은 수치를 나타 내었으며 MLSS는 2,530 mg/1을 나타내었다. 석유화학폐수를 대상으로 폐수가 활성슬러지에 미치는 영향을 조사하기 위하 여 폐수의 희석농도에 대한 활성슬러지의 호흡율을 조사한 결과 Table 2와 같다. 활성슬러지의 호흡율은 기질이 완전히 제거된 내생호흡율과 각 농도에서 활성슬러지의 산소 소비율 의 비로 나타내었으며, 그 결과 석유화학폐수의 경우 생물학 적 처리가 가능한 것으로 판단되었다.

석유화학폐수 처리수의 체류시간은 24 시간으로 초기 조정 하여 분리균주 Neisseria sp. GN13 처리구와 폭기조내에 존재 하는 활성슬러지와 분리균주 Neisseria sp. GN13이 공존할 경

Table 2. Biodegradation test of petrochemical wastewater

\begin{tabular}{lcc}
\hline Characteristics & $\begin{array}{c}\text { Oxygen consumption } \\
\text { rate } \\
(\mathrm{mgO} / \mathrm{mgVSS} / \mathrm{h})\end{array}$ & $\begin{array}{c}\text { Correlation } \\
\text { coefficient } \\
\text { (respiration rate) }\end{array}$ \\
\hline $\begin{array}{l}\text { Endogenous } \\
\text { respiratory rate } \\
\times 10\end{array}$ & 0.4527 & 1.0000 \\
$\times 100$ & 0.3719 & \\
& 0.5416 & 0.8536 \\
\end{tabular}


Table 3. Biological treatment of petrochemical wastewater

\begin{tabular}{lcccc}
\hline \multirow{2}{*}{ Item } & \multirow{2}{*}{ Influent } & \multicolumn{3}{c}{ Effluent } \\
\cline { 3 - 5 } & & Activated sludge & Neisseria sp. GN13 & Neisseria sp. GN13+ Activated sludge \\
\hline $\operatorname{COD}_{\mathrm{Mn}}(\mathrm{mg} / \mathrm{l})$ & 4,378 & $1,619(63 \%)$ & $831(81 \%)$ & $700(84 \%)$ \\
$\mathrm{TOC}(\mathrm{mg} / \mathrm{l})$ & 5,274 & $1,845(64 \%)$ & $1,740(67 \%)$ & $1,634(69 \%)$ \\
$\mathrm{MLSS}(\mathrm{mg} / \mathrm{l})$ & 2,530 & $2,131 \sim 2640$ & $2,017 \sim 2,523$ & $2,348 \sim 2,846$ \\
$\mathrm{pH}$ & 7.00 & $7.04 \sim 7.48$ & $7.02 \sim 7.59$ & $7.03 \sim 7.51$ \\
\hline
\end{tabular}

우 처리효율을 조사하였으며, 대조구로는 활성슬러지를 사용 하였다. 시험 전 2일간 활성슬러지를 공폭기하여 석유화학폐 수에 충분히 순양하도록 적응기간을 두었고 분리균주 Neisseria sp. GN13의 접종량은 초기 $200 \mathrm{mg} / 1$ 을 투여하고, 안정화 기간 동안 매일 $100 \mathrm{mg} / 1$ 씩 투여하였으며 안정화 이후 50 $\mathrm{mg} / \mathrm{l}$ 을 투여하였다. 석유화학폐수의 처리효율은 활성슬러지 와 분리균주 Neisseria sp. GN13을 단독 혹은 혼합 적용하여 10 일 동안 처리효율을 조사한 결과 Table 3 과 같다.

석유화학폐수에 대한 활성슬러지 처리구에서 유출수의 $\mathrm{pH}$ 는 7.04 7.48의 비교적 안정적인 $\mathrm{pH}$ 범위를 나타내었고 활성 슬러지 처리기간 동안의 MLSS 농도는 2,131 2,640 mg/l의 범위를 나타내었으며, 유출수의 COD 농도는 $1,619 \mathrm{mg} / 1$ 로 $63 \%$ 의 제거효율을 나타내었다.

분리균주 Neisseria sp. GN13 처리구에서 유출수의 $\mathrm{pH}$ 범위 는 7.02 7.59이었고 MLSS 농도의 범위는 2,017 2,523 mg/l으 로 활성슬러지 처리구와 유사한 범위를 나타내었다. 10 일간 처리 후 유출수의 COD 농도는 $831 \mathrm{mg} / 1$ 로 $81 \%$ 의 COD 제거 효율을 나타내어 활성슬러지를 처리 하였을 경우 보다 분리균 주 Neisseria sp. GN13을 투입한 경우 더 효율적인 처리가 일어 나는 것을 확인할 수 있었다.

분리균주 Neisseria sp. GN13에 활성슬러지를 혼합한 혼합 처리구에서 $\mathrm{pH}$ 범위는 7.03 7.51로 나타내었고 이때 MLSS의 농도는 2,348 2,846 mg/1의 범위를 나타내어 활성슬러지와 분 리균주 Neisseria sp. GN13만을 처리했을 경우보다 약 10 14\% 정도 증가하였다. 이러한 결과는 활성슬러지에 분리균주가 추 가로 투입되어 미생물 개체군 증가 및 미생물 증식으로 인하 여 MLSS 농도가 증가한 것으로 생각된다. 혼합처리구에서의 $\mathrm{COD}$ 농도는 $700 \mathrm{mg} / 1$ 로 $84 \%$ 의 제거효율을 나타내어 활성슬 러지만을 사용하였을 때 보다 약 1.3 배 증가하였다.

$\mathrm{TOC}$ 제거효율은 활성슬러지 처리구, 분리균주 Neisseria sp. GN13 처리구, 혼합처리구에서 각각 $64 \%, 67 \%$ 와 $69 \%$ 를 나타내어 차이가 거의 나타나지 않았다.

즉 분리균주 Neisseria sp. GN13의 첨가는 $\mathrm{TOC}$ 의 감소보다 는 $\mathrm{COD}$ 제거에 큰 영향을 주는 것으로 나타났다. 이는 대부분 의 탄소원은 활성슬러지에 포함되어있는 미생물에 의해 분해 되어 분리균주 Neisseria sp. GN13의 첨가효과는 크지 않는 것으로 생각된다. Bitzi 등[4]은 여러 가지 미생물이 함께 존재 할 경우 미생물간 발생하는 상호경쟁이 발생할 수 있다고 보
고되었으나, 분리균주 Neisseria sp. GN13의 경우 활성슬러지 에 같이 혼합하여 투입 하더라도 서로 저해하지 않고 석유화 학폐수를 효과적으로 처리하는 것으로 나타났다.

난분해성 방향족물질인 phenol의 분해균주로 개발된 Neisseria sp. GN13은 안정성 연구와 현장적응 과정을 거쳐 사용할 경우 phenol 함유 폐수에 효과적으로 적용할 수 있을 것으로 생각되며, 또한 석유화학 산업폐수의 효율적인 생물학 적 처리를 위하여, 다른 석유계화합물 분해 미생물과 함께 복 합미생물제제화 연구가 수반 되어야 할 것으로 생각된다.

\section{감사의 글}

본 연구는 2011년 국립 경남과학기술대학교 기성회의 연구 비 지원을 받아 수행되었습니다.

\section{References}

1. Aldrich, T. L., Frantz, B., Gill, J. F., Kilbane, J. J. and Chakrabarty, A. M. 1987. Cloning and complete nucleotide sequence determination of the cat B gene encoding cis, cis-muconate lactonizing enzyme. Gene 52, 185-195.

2. Apajalahti, J. H. A. and Salkinoja-Salonen, M. S. 1986. Degradation of polychlorinated phenols by Rhedococcus chlorophenolicus. Appl Microbiol Biotechnol 25, 62-67.

3. APHA, AWWA, and WEF. 1992. Standard methods for the examination of water and wastewater. 18th eds., APHA, Washington

4. Bitzi, U., Egli, T. and Hammer, G. 1991. The biodegradation of mixtures of organic solvents by mixed and monocultures of bacteria. Biotechnol Bioeng 37, 1037-1042.

5. Gibson, J. M., Thomas, P. S., Barker, J. L., Chandran, S. S., Harrup, M. K., Draths, K. M. and Frost, J. W. 2001. Benzenefree synthesis of phenol. Angew Chem Int 40, 1945-1948.

6. Gordon, A. H. and Compbell, W. R. 1975. Substrate inhibition kinetics ; phenol degradation by Pseudomonas putida Biotech Bioeng 17, 1599-1615.

7. Haggblom, M. M. 1992. Microbial breakdown of halogenated aromatic pesticides and related compounds. FEMS Microbiol Rev 103, 29-72.

8. Hegeman, G. D. 1966. Synthesis of the enzymes of the mandelate pathway by Pseudomonas putida: I. Synthesis of the enzymes by the wild type. J Bacteriol 91, 1140-1154.

9. Hinteregger, C., Laitner, R., Loidl, M., Ferschl, A. and 
Streichsbier, F. 1992. Degradation of phenol and phenolic compounds by Pseudomonas putida EKII. Appl Microbiol Biotechnol 37, 252-259.

10. Japanese Sewage Works Association. 1984. Methods for Sewage Analysis Japanese Sewage Works Association. Tokyo, Japan

11. Kiyohara, H., Hatta, T., Ogawa , Y., Kakuda, T., Yokoyama, H. and Takizawa, N. 1992. Isolation of Pseudomonas pikettii that degrade 2,4,6-trichlorophenol and their dechlorination of chlrorophenols. Appl Environ Microbiol 58, 1276-1283.

12. Ko, Y. H., Ha, I. H. and Bae, K. S. 1988. Iolation and Characterization of a Naphtalene Degrading Strain, Pseudomonas putida N3. Korean J Appl Microbiol Biotechnol 16, 199204.

13. Lee, C. H., Oh, H. M., Kwon, T. J., Kwon, G. S., Lee, S. G., Suh, H. H. and Yoon, B. D. 1994. Isolation and Characterization of a Phenol-Degrading Strain, Acinetobacter sp. GEM2. Korean J Appl Microbiol Biotechnol 22, 692-699.

14. Leisinger, T., Cook, A. M., Hutter, R. and Nuesch, J. 1981. Microbial degradation of xenobiotics and recalcitrant compounds. Academic Press. Zurich.

15. Li, J. K. and Humphrey, A. E. 1989. Kinetics and fluorometric behaviour of a phenol fermentation. Biotechnol Lett 11, 177-182.

16. MacFaddin, J. F. 1984. Biochemical tests for identification for medical bacteria. 2nd eds,. Williams \& Wilkins Co., Baltimore, Maryland.

17. Martin, R. W. 1949. Rapid colorimetric estimation of phenol.
Anal Chem 21, 1419-1420.

18. Masque, C., Nolla, M. and Bordons, A. 1987. Selection and adaptation of a phenol-degrading strain of Pseudomonas. Biotechnol Lett 9, 655-660.

19. Nordlund, J. and Shingler, V. 1990. Nucleotide sequence of the meta-clevage pathway enzyme 2-hydroxymucoic semialdehyde dehydrogenase and 2-hydroxymuconic semialdehyde hydrolase from Psedomanas CF600. Biochem Biophys 1049, 227-320.

20. Nozaki, M. 1970. Metapyrocatechase (Pseudomanas), Methods in enzymology 17A. Academic Press, New York.

21. Peter, H. A. S., Nicholas, S. M., Sharpe, M. E. and Holt, J. F. 1986. Bergey's manual of systematic bacteriology, Williams and Wikins Co., Baltimore, Maryland.

22. Rand, G. H. and Petrocell, S. R. 1985. Fundamentals of aquatic toxicology. Hemisphere Publishing Company. Washington.

23. Sariaslami, F. S. 2007. Development of a combined biological and chemical process for production of industrial aromatics from renewable resources. Annu Rev Microbiol 61, 51-69.

24. Shingler, V., Powlowski, J. and Marklund, U. 1992. Nucleotide sequence and functional analysis of complete phenol 3,4-dimethylphenol catabolic pathway of Pseudomonas sp. strain CF600. J Bacteriol 174, 711-724.

25. Tamaoka, K. and Komagata, K. 1984. Determination of DNA base composition by reversed-phase high-performance liquid chromatography. FEMS Microbiol Lett 25, 125-128.

초록 : Phenol 분해균주의 분리 및 페놀함유 폐수의 생물학적 처리

이현돈 · 이명은 · 김형갑·서현효*

(국립경남과학기술대학교 환경공학과)

방향족화합물들로 오염되어있는 토양 및 산업폐수를 포함한 각종 시료로부터 phenol에 분해활성이 높은 56균 주를 순수분리 하였으며, 이들 분리 균주 중 균체생육과 phenol 분해활성이 가장 높은 균주인 GN13을 선별하였 다. 분리균주 GN13은 형태학적, 생리학적 및 생화학적 특성을 조사한 결과 Neisseria 속 세균과 유사한 것으로 판명되어 최종적으로 Neisseria sp. GN13으로 명명하였다. 분리균주 Neisseria sp. GN13의 균체생육 및 phenol 분

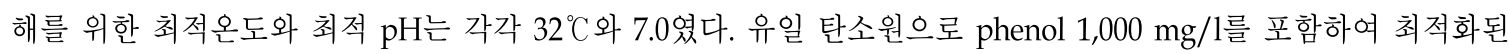
배지를 사용한 jar-fermentor 배지에서 배양 30 시간에 균체생육이 최대에 이르렀으며 배양 27 시간째 거의 모든 phenol이 분해되었으며, catechol deoxygenase 활성측정에 의하여 Neisseria sp. GN13은 metz와 orthopathway를 통하여 catechol 분해가 일어났다. Neisseria sp. GN13은 phenol 함유 인공폐수에서의 phenol 분해율은 배양 30시 간 만에 $97 \%$ 의 phenol이 분해되는 것으로 나타났으며, 인공폐수에 대한 Neisseria sp. GN13과 활성슬러지 처리구 에서의 TOC 제거효율은 각각 $83 \%$ 와 $78 \%$ 였다. 석유화학폐수에 대한 Neisseria sp. GN13의 COD 제거율은 활성슬 러지만을 포함한 대조구보다 약 1.3 배 높은 효율을 나타내었다. 이러한 결과로 미루어 분리균주 Neisseria sp. GN13은 phenol을 함유하고 있는 여러 폐수에 효과적으로 적용될 수 있을 것으로 생각된다. 